\title{
COASTAL AND MARINE TOURISM IN THE INDIAN OCEAN RIM ASSOCIATION STATES: OVERVIEW AND POLICY CHALLENGES
}

\author{
Christian M. ROGERSON* \\ University of Johannesburg, School of Tourism \& Hospitality, College of Business \\ \& Economics, Bunting Road, Johannesburg, South Africa, email: chrismr@uj.ac.za
}

\begin{abstract}
Citation: Rogerson, C.M., (2020). COASTAL AND MARINE TOURISM IN THE INDIAN OCEAN RIM ASSOCIATION STATES: OVERVIEW AND POLICY CHALLENGES. GeoJournal of Tourism and Geosites, 29(2), 715-731. https://doi.org/10.30892/gtg.29226-501
\end{abstract}

\begin{abstract}
Inclusion' represents one of the central principles behind the United Nations Sustainable Development Goals. This article investigates the development of coastal tourism in the Indian Ocean Rim Association (IORA) states and accompanying broad policy challenges. Special focus is on the leveraging of coastal and marine tourism for an inclusive tourism economy. Coastal and marine tourism is a vital expanding segment of the global tourism economy and acknowledged as a critical sector of the Blue Economy across IORA states. Arguably, the significant assets of coastal and marine tourism offer considerable potential for tourism development across IORA states. Multiple challenges confront the sustainable development of coastal and marine tourism including lack of (or inappropriate) planning for coastal area development and management, governance issues, limited innovation, access to finance for enterprise development, absence of data for monitoring, and, the severe threats posed to coastal destinations from advancing climate change. Above all, the imperative for economic inclusion and of achieving a greater spread of the benefits of tourism growth to local communities, especially for marginalised groups, is a critical policy issue. For many IORA states this might require a rethink of the dominant planning model around encouraging mass international tourism (which is often concentrated on all-inclusive resorts or cruise tourism) and instead the reconsideration of the potential for leveraging potential benefits from promoting domestic and regional travel as well as of budget forms of international tourism.
\end{abstract}

Key words: coastal and marine tourism; Indian Ocean Rim; policy challenges; economic inclusion; inclusive tourism

\section{INTRODUCTION}

Wong (1986: 152) maintains that "if there is one category of tourism that stands out from other forms of tourism, it is likely to be that of coastal tourism". Indeed, coastal areas are highly valued environments for recreational pursuits with travel to coastal

\footnotetext{
* Corresponding author
} 
destinations for leisure purposes recognised as having a long ancestry (Prideaux, 2004, 2009; Gupta, 2015; Walton, 2016; Rogerson \& Rogerson, 2020a). Within the present global tourism economy coastal tourism for leisure purposes is viewed as one of its most rapidly expanding segments (Miller, 1993; Agarwal \& Shaw, 2007; Honey \& Kranz, 2007; Dwyer, 2018; Rogerson \& Rogerson, 2020b). Annually millions of leisure tourists flock to pleasure resorts in coastal environments of the Mediterranean, the Caribbean and many Small Island Developing States of the Indian Ocean where the tourism sector is the anchor for sustainable economic development (Hampton \& Jeyacheya, 2013; Orams \& Luck, 2014; Gössling et al., 2018). Carvache-Franco et al. (2020) point out that coastal destinations increasingly offer a variety of activities for experiencing contact with nature (and culture) beyond that of the traditional coastal tourism product offering that focuses on the sun and the beach. In many countries a government policy focus around coastal and marine tourism is part of a broader assessment and policy development for the 'blue' or ocean economy. Although the definition of the blue economy is contested it refers generally to maximisation of the economic potential of ocean resources balanced by the need to ensure ocean health and sustainability (Colgan, 2017; Potgieter, 2018; Rogerson \& Rogerson, 2019a; Verma \& Jolly, 2019). The World Bank (2017: 22) estimates that tourism accounts for a roughly 26 percent of ocean-based economic activity and is "a key driver of the blue economy". Not surprisingly, therefore, for many coastal destinations planning for tourism development constitutes a key theme within local economic development programming in many countries (Prideaux, 2009; Rogerson \& Rogerson, 2019b). Conflicts arise, however, as coastal spaces provide multiple activities and uses and external forces often lack consideration for traditional coastal uses particularly in global South environments (Käyhkö et al., 2019).

The standard definition of coastal and marine tourism is clarified by Hall (2001: 602) as follows: "The concept of coastal tourism embraces the full range of tourism, leisure, and recreationally oriented activities that take place in the coastal zone and the offshore coastal waters. These include coastal tourism development (accommodation, restaurants, food industry, and second homes), and the infrastructure supporting coastal development (e.g. retail businesses, marinas and activity suppliers). Also included are tourism activities such as recreational boating, coast- and marine-based ecotourism, cruises, swimming, recreational fishing, snorkelling and diving. Marine tourism is closely related to the concept of coastal tourism but also includes ocean-based tourism such as deep-sea fishing and yacht cruising”. Among others, Orams \& Luck (2014) point out that the domain of coastal and marine tourism is expanding and an increasingly important component of the international tourism economy. Globally, Dwyer (2018: 29) estimates that coastal and marine tourism generated a total Gross Value Added (GVA) in 2010 of US\$ 390.11 billion and employed 6.9 million people; by 2030 it is projected to produce a GVA of $\$ 777.14$ billion with an expansion of employment to 8.6 million in total. The projected $3.5 \%$ annual growth in coastal and marine tourism to 2030 exceeds the projections made by the United World Tourism Organisation (UNWTO) of $3.3 \%$ annual growth for tourism as a whole (Dwyer 2018: 30). Arguably, the expansion of the coastal and marine tourism sector can have the potential to catalyse several opportunities for small, medium and micro-enterprises (SMMEs) for local entrepreneurs to enhance the sector's developmental potential and local destination impacts (Attri, 2018; Rogerson, 2020).

The aim in this paper is to examine the core policy challenges facing the development of coastal tourism in the Indian Ocean Rim Association (IORA) states. Special focus is on the challenges for the leveraging of coastal and marine tourism for an inclusive tourism economy. 'Inclusion' represents one of the central principles behind the United Nations Sustainable Development Goals which were agreed to in September 2015 
(UNCTAD, 2017). The movement toward inclusion addresses the fact that certain groups or communities often are 'left out of development' processes (Scheyvens, 1999, 2002a; Käyhkö et al., 2019). Within tourism studies there is a growing interest for investigating the extent to which the sector is 'inclusive' and to isolate the drivers as well as the challenges to achieving an inclusive tourism pathway (Biddulph \& Scheyvens, 2018; Hampton et al., 2018; Scheyvens \& Biddulph, 2018; Rogerson, 2020).

\section{MATERIALS AND METHODS}

The major work undertaken for this study was an internet-mediated desk-top research on coastal and marine tourism with special scrutiny upon issues around economic inclusion and SMME development. The focus in this research was identifying critical debates in coastal and marine tourism and on policy for 'good practice' concerning economic inclusion in the states of the Indian Ocean Rim Association (IORA). In terms of the project tasks, of particular relevance was a search conducted through Google Scholar of the most influential and relevant research on these themes appearing in books, monographs and most importantly of research outputs published in scientific peer-reviewed scholarly journals in tourism and in the field of ocean and marine science. In terms of academic journals, rich material was sourced also from two serials which are geographically dedicated to the Indian Ocean Region. First, is the Journal of the Indian Ocean Region which "is to facilitate a regional voice in the identification, research and analysis of policy issues of common regional concern" (Indian Ocean Research Group, 2010: 1). Second, is the recently-established Journal of Indian Ocean Rim Studies, which is the flagship serial of the IORA Academic Group.

Although the scholarly material discussed above provides the core source material for this article other data and complementary information was mined from international agencies engaged with tourism. Baseline data on international tourism arrivals, receipts and tourism contribution to GDP in IORA states was obtained from the United Nations World Tourism Organisation (UNWTO, 2017). Useful additional material on IORA was secured through internet sources and from information provided through the presentations made at the 3rd Tourism Experts Meeting for the Establishment of the IORA Core Group on Tourism held in May 2018 at Durban, South Africa (Attri, 2018). A further valuable documentary source is the recent appearance of a blue economy handbook of the Indian Ocean region (Attri \& Bohler-Muller, 2018).

\section{IORA AND THE BLUE ECONOMY}

IORA was established as an inter-governmental organisation on 7 March 1997 with the goal of ensuring peace and prosperity in the Indian Ocean Region. The vision for IORA originated in 1995 during a visit to India by South Africa's first democratic president, Nelson Mandela who stated that the "natural urge of the facts of history and geography... should broaden itself to include the concept of an Indian Ocean Rim for socio-economic cooperation and other peaceful endeavours. Recent changes in the international system demand that the countries of the Indian Ocean shall become a single platform". At its founding in 1997 IORA had 14 members, namely Australia, India, Indonesia, Kenya, Madagascar, Malaysia, Mauritius, Mozambique, Oman, Singapore, South Africa, Sri Lanka, Tanzania and Yemen. Expansion occurred in 1999 with the accession to membership of Bangladesh, Iran, Thailand and the United Arab Emirates.

Since 2010 three further new countries have been added to IORA, namely Seychelles (2011), Comoros (2012) and Somalia (2014). In addition to its 21 member states IORA also has seven dialogue partners, namely China, Egypt, France, Germany, Japan, United Kingdom and United States (Attri \& Bohler-Muller, 2018). According to 
Attri (2019: 11) the major focus of IORA needs to be on regional economic cooperation to achieve balanced development and growth in the region for the prosperity of the Indian Ocean Region. For Attri (2019) this includes a cluster of challenges including promoting the Fourth Industrial Revolution which comprises of disruptive technologies and trends such as robotics, virtual reality, artificial intelligence and the Internet of Things all of which are transforming the way people live and work. The attainment of the 2030 United Nations Sustainable Development Goals can be leveraged through a focus on Science, Technology and Innovation. Of critical importance for balanced growth is cooperation for a Sustainable Blue Economy, including coastal and marine tourism (Attri, 2019). All this said, as pointed out by Manwa (2019), the central role accorded to coastal and marine tourism does not mean overlooking the competitive potential of other forms of tourism such as cultural and heritage tourism.

Coastal and marine tourism is identified as a vital Blue Economy sector by several IORA countries, with the IORA Action Plan for 2017-2021 specifically isolating the theme of 'Tourism and Cultural Exchanges' as one of its key priority areas (IORA, 2018). In 2017 with South Africa's accession to the position of Chair of IORA, the national Minister of International Relations and Cooperation declared that the country "looks forward to an increased focus on tourism, a critical sector with enormous opportunities for enhanced cooperation towards improved economic growth and development within IORA" (IORA, 2018). A linkage was forged now between IORA's prioritisation of coastal and marine tourism on the one hand, and tourism SMME development on the other, in particular as the latter was highlighted in both the IORA Action Plan 2017-2021 and by the Durban Communique which was issued at the 17th meeting of IORA Council Ministers.

Arguably, the tourism sector is one of the largest sectors of employment in the blue economy of several IORA member states (Dwyer, 2017). Accordingly, over the past 20 years coastal and marine tourism has assumed an increasingly vital role in IORA policy processes particularly in the context of blue economy debates. Indeed, for Doyle (2018: 1) the blue economy, which broadly conceptualizes the oceans as 'shared development spaces', "has emerged as a powerful and contested concept in many of those 27 countries which are part of, either as Member States or Dialogue Partners, the leading Track One regional government organization: the Indian Ocean Rim Association”. The Blue Economy debates are especially relevant in this region as in geopolitical terms the Indian Ocean Rim is shifting away "from being identified as the 'Ocean of the South' to the 'Ocean of the Centre', and 'the Ocean of the Future' (Doyle, 2018: 1). Although there is no clear consensus on the definition of the blue economy it is argued that in policy terms "at the core of the concept is the awareness of maritime resources and their capacity to contribute to poverty reduction, human welfare and economic opportunity" (Doyle, 2018: 1). Further it is added that such maritime resources must be used in a sustainable, stable and inclusive manner. Indeed, the critical importance of sustainable resource use is underlined by observations of dramatic population growth in the population of Indian Ocean Rim Countries with projections that by 2050 the region might include almost half of the world's population.

Attri (2017) documents that at the 20th Anniversary celebrations in Jakarta, Indonesia the first ever IORA leaders' summit was hosted under the theme of "Strengthening Maritime Cooperation for a Peaceful, Stable and Prosperous Indian Ocean”. Discussions at the Summit covered the current situation faced within the Indian Ocean Rim and culminated in the declaration of the Jakarta Accord by the leaders. One of six commitments relates to promotion of cooperation in 'tourism and culture'. As Attri (2017) points out beyond the six areas of cooperation IORA leaders were also encouraged to strengthen their mutual cooperation in other issues, most importantly the Blue Economy. The October 2014 IORA 'Blue Economy' Declaration signalled a regional 
commitment to enhance collaboration in an array of different areas (Doyle, 2018). The deepening strategic importance of cooperation around the Blue Economy represents a logical outcome of further IORA consultations. At the first and second Ministerial Blue Economy Conferences held respectively on 2-3 September 2015 in Mauritius and 9-10 May 2017 in Jakarta the essential role for human well-being and social and economic development was acknowledged of oceans along with coastal and marine resources. The 'Jakarta Declaration on the Blue Economy', issued May 2017, provides a total of 26 recommendations as well as principles for developing and applying blue economy approaches to sustainable development and enhancement of socio-economic benefits, particularly for coastal communities in the IORA region (IORA, 2017). As part of advancing gender equality Rimmer (2017) as well as Kotze \& Bohler-Muller (2018) remind us that at the heart of sustainable development for the IORA countries must be the imperative for women's economic empowerment.

Prior to the Jakarta declaration it must be acknowledged that several IORA states have been engaged in developing aspects of the blue economy for many decades, albeit with varying levels of success and commitment (Doyle, 2018). Fisheries, offshore oil and gas, maritime industries and tourism are viewed as "already making a significant contribution to the economies of the Indian Ocean states" (Llewellyn et al., 2016: 52). It is evident that IORA is fully cognisant of serious challenges which are caused by natural and human factors such as overexploitation of resources, increasing marine pollution, biodiversity loss, and the impacts of global climate change. What is new, however, is an extended acknowledgement of the importance and potential of the blue economy among certain IORA states. For example, Mittra (2017: 1) records that the blue economy "presents a unique and unprecedented opportunity for India to reframe its approach in managing the ocean". Likewise, in the case of Bangladesh, Hussain et al. (2018) acknowledge "major opportunities" and argue that, with its underdeveloped blue economy, the country is well positioned to develop untapped sectors including tourism.

Among several academic observers the critical potential is flagged of forging a common pathway towards "sustainable blue economic growth" among Indian Ocean nations (Llewellyn et al., 2016: 52). In a useful contribution Colgan (2017) stresses that the region's imperatives for "transformative development capable of addressing the profound needs for vital economies and poverty alleviation that is simultaneously environmentally responsible including adjusting to the profound challenge of climate change" underscore the research challenge of a greater understanding of the key individual segments of the blue economy. One critical sector now identified within blue economy debates across IORA states is tourism, which is a major employment sector, part of the diversification strategies of several states, and source of valuable income for coastal communities. Colgan (2017: 23) considers tourism "is the blue economy sector which is most dependent on the development of appropriate infrastructure" which would include airports, roads and passenger seaports. It is essential to recognise also that there are consequences for coastal and marine tourism which arise both from its own growth as well as from the operations of other established and emerging segments of the blue economy (Dwyer, 2018). Fostering the expansion of tourism as well as harnessing and developing the blue economy in the IORA region are two crucial issues that are highlighted as part of the IORA Action Plan for 2017-2021. The IORA Action Plan identified in its shortterm actions the establishment of a Core Group on Tourism which would "assess the importance of the sector in the Indian Ocean Region and how the Member States of the Association with the support of the Dialogue Partners could develop a sustainable job creating and development framework" (IORA, 2018). The next section turns to overview the role and character of tourism in IORA states and specifically of coastal and marine tourism. 


\section{THE ROLE OF COASTAL TOURISM IN THE IORA BLUE ECONOMY}

Arguably, measuring the contribution of certain components of the Blue Economy - fisheries, offshore oil and gas or aquaculture - can be done with a relative degree of accuracy (Dwyer, 2018). By contrast, the measurement of the contribution of tourism and assessment of its impacts across countries is problematic for several reasons. The tourism sector does not fit Standard Industrial Classifications rather it is "a diffuse and multiple industry consisting of closely associated and interacting segments such as transportation (international and domestic); accommodation; intermediaries such as tour operators and travel agents; catering services; retail such as souvenirs; local attractions and activities; vehicle rental and so forth" (Hampton et al., 2018: 362). In addition, differing definitions are applied in countries for classifying 'tourists' (day visitors as opposed to overnight visitors) and often generally weak systems of data collection (particularly in countries of the global South) result in unreliable or unavailable tourism data for many nations. With these caveats in mind this section aims to provide a profile of tourism in IORA states and offer a picture of the state of coastal tourism.

Table 1. The State of International Tourism in IORA Countries

\begin{tabular}{|c|c|c|c|c|c|}
\hline Country & $\begin{array}{c}\text { Length of } \\
\text { Coastline (km) }\end{array}$ & $\begin{array}{l}\text { International } \\
\text { Tourism } \\
\text { Arrivals } 2016\end{array}$ & $\begin{array}{c}\text { International } \\
\text { Tourism } \\
\text { Receipts (US } \\
\text { \$million) }\end{array}$ & $\begin{array}{c}\text { Travel \& } \\
\text { tourism industry } \\
\% \text { GDP }\end{array}$ & $\begin{array}{l}\text { Travel \& Tourism } \\
\text { Projected GDP } \\
\text { annual growth } \\
\text { rate, 2013-2022 }\end{array}$ \\
\hline Australia & $25760 \quad(2)$ & $8263 \quad(8)$ & $32423 \quad$ (2) & $2.6(16)$ & $3.4(16=)$ \\
\hline Bangladesh & $580(16)$ & 125 (19) & $175(17)$ & $2.1(18)$ & $6.1(4=)$ \\
\hline Comoros & 340 (19) & $24(20)$ & $40(20)$ & No data & No data \\
\hline India & $7000 \quad(3)$ & $14569 \quad(4)$ & $22427 \quad(3)$ & $2.0 \quad(19)$ & $6.4 \quad(2)$ \\
\hline Indonesia & $54716 \quad$ (1) & $9963 \quad(7)$ & $11349 \quad(7)$ & 3.1 (12) & $5 \cdot 3 \quad(9)$ \\
\hline Iran & $3180 \quad(7)$ & $4942 \quad$ (9) & 3868 (9) & 2.2 (17) & $5.7 \quad(7)$ \\
\hline Kenya & 536 (17) & $1114(14)$ & $824(14)$ & $4.8 \quad(7)$ & $5.2(10)$ \\
\hline Madagascar & $4828 \quad(4)$ & $293(18)$ & 307 (16) & $5.9 \quad(5)$ & 5.1 (11) \\
\hline Malaysia & $4675 \quad(5)$ & $26757 \quad$ (2) & 18074 (6) & $7.2 \quad(4)$ & $4.4(12=)$ \\
\hline Mauritius & $177(21)$ & $1275(13)$ & 1572 (12) & $11.3 \quad(2)$ & $4.4(12=)$ \\
\hline Mozambique & $2470(10)$ & 1639 (12) & $108(18)$ & 3.2 (11) & $6.1(4=)$ \\
\hline Oman & 2092 (11) & 1897 (11) & $1540(13)$ & $3.0(14)$ & $5.4 \quad(8)$ \\
\hline Seychelles & 491 (18) & $303(17)$ & 414 (15) & 21.2 (1) & $4.3 \quad(14)$ \\
\hline Singapore & $193(20)$ & $12913 \quad(5)$ & $18386 \quad$ (5) & $5 \cdot 3(6)$ & $3.4(16=)$ \\
\hline Somalia & $3025 \quad(8)$ & No data & No data & No data & No data \\
\hline South Africa & $2881 \quad(9)$ & $10044 \quad(6)$ & $7910 \quad(8)$ & $3.0 \quad(13)$ & $3.9 \quad(15)$ \\
\hline Sri Lanka & $1340(15)$ & $2051(10)$ & 3518 (10) & $3.9(10)$ & $6.1 \quad(4=)$ \\
\hline Tanzania & $1424(14)$ & $1104(15)$ & 2135 (11) & $4.5 \quad(8)$ & $6.2 \quad(3)$ \\
\hline Thailand & $3219 \quad(6)$ & $32588 \quad(1)$ & $49871 \quad$ (1) & $9.0 \quad(3)$ & $6.7 \quad(1)$ \\
\hline $\begin{array}{l}\text { United Arab } \\
\text { Emirates }\end{array}$ & 1448 (13) & $14910 \quad(3)$ & 19496 & 4.0 & 3.1 \\
\hline Yemen & 1906 (12) & $367(16)$ & 100 (19) & $2.9 \quad(15)$ & 2.4 (19) \\
\hline
\end{tabular}

Sources and Notes: (1) Coastal data from Miller \& Auyong, 1991; different methods are used by certain organisations to calculate length of coastline; (2) Data on tourism arrivals and receipts from UNWTO (2017). For most countries arrivals and receipt data is for 2016 but when unreported for 2016 the most recent available data is included; for India international tourism arrivals are increased by the inclusion of day visitors which would not be classed as tourism in most countries; (3) GDP data and projected estimates are from UNWTO and are provided in Dwyer, 2017, p. 39. (4) Numbers in bracket reflect rank of countries. 
The UNWTO data is highly cited as a baseline for measurement of international tourism and of the relative contribution of tourism to GDP. Table 1 provides a situation analysis of the state of tourism in IORA countries using recent UNWTO (2017) data. The UNWTO projects that the volume of international tourism is expected to increase worldwide by an average 3.3 percent a year from 2010 to 2030 which would result in 1.4 billion international tourists by 2020 and 1.8 billion by 2030. Several points must be noted about Table 1. First, the UNWTO international tourism data relates to all destinations and not simply to coastal destinations. In several IORA states there are significant destinations for international travel which are non-coastal destinations; many of these destinations, such as Kuala Lumpur, Delhi, Jakarta, Johannesburg or Tehran, represent important business tourism destinations for international travel. Second, the data reveals an extraordinary range in the numbers of international tourists and of estimated tourism receipts across the 21 IORA states. In terms of ranking by numbers of tourist arrivals the list is headed by Thailand, Malaysia, United Arab Emirates and India; Somalia, Comoros, Bangladesh and Madagascar record the lowest totals of arrivals. In terms of ranking by international tourism receipts a different order emerges with Thailand, Australia, India and United Arab Emirates the leading countries and Somalia, Comoros, Yemen and Mozambique the least significant. The much higher ranking of Australia in receipts as compared to total arrivals is indicative of high average spend of that country's cohort of international tourists as compared to, for example, the case of Mozambique where the lower rank in terms of receipts as compared to arrivals is explained by the much lower average spend per international arrival. Three, it must be understood that several IORA destinations recently have experienced considerable volatility in international tourism arrivals because of political instability, civil conflict or terrorism; examples would be Comoros, Kenya, Madagascar, Somalia and Yemen.

Four, the accuracy of data on tourism contribution to GDP must be again treated with some caution as offering only the broadest sketch across the IORA states. This said, it highlights that several countries such as Seychelles, Mauritius, Thailand, Malaysia and Madagascar record significant contributions of international tourism to GDP; in relative terms the countries for which international tourism contributes the smallest proportions of GDP are Iran, India, Bangladesh, and most probably Somalia for which no data is available. Five, the UNWTO data for future growth in terms of contribution of international tourism to GDP point to the fastest growth potentially occurring in Thailand, India, Tanzania, Mozambique and Sri Lanka. By contrast, the more longestablished and 'mature' international tourism destinations of Australia, South Africa, Singapore and the United Arab Emirates as well as conflict-ridden Yemen are projected to record the lowest rates of expanded contribution for international tourism to national GDP. Six, an important point to consider concerning the tourism statistics as shown on Table 1 is to recognise that a substantial (but often unknown or unrecorded) proportion of this expanding economy of 'international tourism' is accounted for by 'regional tourism'.

Several studies stress the enormous recent upsurge of 'intra-regional' travel particularly in Asia but also for sub-Saharan Africa (Ghimire, 2001). Multiple factors coalesce and account for increases in intra-regional mobilities. Most significant are improved economic prosperity associated with the growth of urbanization, the rise in discretionary income in the hands of expanding middle classes, and the facilitating role played by the emergence of budget airlines which offer affordable and faster connections between numerous regional destinations. Taken together with the relaxation of visa controls and improved intra-regional road connectivities there has occurred a substantial growth of 'regional tourism' by middle classes as well as even of less affluent strata which can take advantage of reduced costs and ease of travel between countries (Cohen \& Cohen, 2015). 
Arguably, this growth in 'regional tourism' as part of international tourism frequently is ignored in analyses of international tourism and its impacts for particular countries. Indeed, for IORA states it is simply incorrect to assert, as does Dwyer (2017: 40), that "intra-regional travel remains relatively limited". In the example of Mozambique the vast majority of its cohort of international tourists are arrivals either from neighbouring South Africa or Malawi. Likewise, in the case of South Africa of the country's estimated total of 10 million international tourists almost 80 percent originate from sub-Saharan Africa, the majority from proximate states of the Southern African Development Community (Rogerson, 2004). Across Asia the proliferation of budget airlines has boosted massively the intra-regional flows of tourists with the clearest examples that of Malaysia-Singapore-Indonesia. The critical importance of unpacking the role of 'regional tourism' in IORA states is underlined by the different characteristics, often different travel motivations and markedly different impacts upon local economies of regional tourists as opposed to the long-haul international traveller.

Typically regional trips are of shorter duration, cheaper than long-haul travel, and involve different expenditure patterns in the host destinations with compelling evidence of greater impacts for local economies from regional as opposed to long haul international travellers because of reduced leakages (Cohen \& Cohen, 2015). Seven, Miller \& Auyong (1991: 76) state that there are "no standardized practices for reporting tourism statistics within the coastal zone". In global terms the absence of international statistics makes it difficult to determine the share of coastal and marine tourism in global tourism (Dwyer, 2018). Likewise, Dwyer (2017) points out that it is not possible to determine accurately the precise contribution of coastal and marine tourism in IORA states. Several methodological challenges surround the measurement of the impact of coastal and marine tourism (Bob et al., 2018). As noted earlier, in several IORA states there are important tourism destinations which are non-coastal in their geography.

Only in the case of the Small Island Developing States (SIDS) of Seychelles, Comoros and Mauritius can one argue that almost the entire contribution of international tourism arrivals be attributed to coastal destinations. All this said, Daldeniz \& Hampton (2013: 507) observe that across the global South international tourism "is often spatially concentrated at the coast, ranging from so-called $3 \mathrm{~S}$ (sun, sea and sand) mass tourism, to the increasing growth of more active leisure as exemplified by the rapid expansion of scuba diving". In most IORA states it is evident that tourism has a major coastal presence (Harriott, 2004; De Brauwer et al., 2017; Attri, 2018; Kinseng et al., 2018; Al Busaidi et al., 2019). Some illustrative examples follow. In the case of Southeast Asia, including the cases of Thailand, Indonesia, Malaysia and Singapore, Wonga (1998) stresses that the regional states possess the basic resources for coastal tourism in terms of sandy beaches, coral reefs, thousands of islands and a rich cultural heritage to complement coastal tourism development ranging from basic A-frame huts to integrated resorts. Hampton \& Jeyacheya (2014) confirm coastal tourism is expanding rapidly across Southeast Asia, especially on small islands.

They highlight significant management issues in terms of planning for the rapid growth of leisure tourism whilst retaining vital economic benefits for local communities. Again, with a focus on Malaysia, Lee (2010) records the expansion of coastal resorts, hotels and tourism related infrastructure. For Bangladesh, the 'undiscovered gem of Asia', Rahman (2015) documents the potential for expanded tourism at Cox's Bazaar with its 125 kilometre long unbroken sandy beach that is reputedly the largest in the world.

Beyond IORA states in Asia the critical economic importance and developmental potential of coastal tourism is also well-documented. In Australia, the best examples are mass beach tourism at Queensland's Gold Coast and marine tourism at the Great Barrier 
Reef (Spalding et al., 2017). Van Putten et al. (2016) document that marine tourism is now the largest employer in small regional coastal communities across all states of Australia. For large parts of Africa, including Kenya, Mozambique and Tanzania, Leijzer \& Denman (2014: 1) show coastal areas exhibit a "high potential for tourism development". Despite its iconic safari and nature tourism attractions, in Kenya coastal tourism was attributed for generating 60 percent of tourism's contribution to GDP (The COAST Project, 2013). Based upon its project work in Kenya, Tanzania and Mozambique the UNWTO (2013:3) endorses the view that "coastal tourism in Africa can bring significant benefits for the local economy, society and the environment, such as revenue generation, employment creation, infrastructure development, conservation of the cultural and natural heritage, and can offer an alternative and sustainable source of livelihood for local communities".

Elsewhere in East Africa, the growth and potential of coastal tourism in Zanzibar is well-recorded (Anderson, 2013; Murphy, 2019). In the example of Mozambique the country's beach resources, opportunities for dive tourism and viewing manta rays are considered as major tourist drawcards (Tibirica et al., 2011; Venables et al., 2016; Snyman \& Spenceley, 2019). In Oman considerable interest surrounds the current status and future potential of sustainable sea turtle tourism (Al Busaidi et al., 2019). Finally, the possibilities for leveraging assets for the development of coastal and marine tourism in the remaining IORA states - including United Arab Emirates, Iran, Madagascar, Yemen and even Somalia - are documented by Attri (2018) in a recent comprehensive overview.

The dominant focus in marketing for coastal tourism in many IORA African and Asian countries is that of the mass international tourism market either in all inclusive resort developments or in terms of mass tourism through cruise tourism. Nevertheless, it should be recognised that in other countries - most obviously Australia - domestic tourism is the leading component in the volume of trips to coastal tourism destinations. Further evidence exists in research reported about other IORA states to confirm the importance of domestic tourists in coastal destinations. The best illustration is of Goa in India, which is viewed as a classic beach destination for international tourism.

Amongst the 'paradoxes' of Goa tourism Wilson (1997) shows the rise and significance of the lower-budget domestic tourists in this destination. Several advantages are observed of domestic tourism flows to Goa. Wilson (1997: 71) notes as follows: "Nor is it as fickle and as vulnerable as international tourism, it does not require so much foreign exchange to develop, it is less dependent on foreign airlines and tour operators, it is less subject to seasonality, it has less of a colonial character, and it can help foster national integration". Overall the significance of domestic tourism is overlooked in several analyses of tourism in IORA states. This said, domestic tourism constitutes at least 80 percent of tourism flows on a global basis; and, from other observers the figure is higher and domestic tourists might be as much as 10 times larger than international tourism flows (Scheyvens, 2007: 308). Domestic tourists are known to represent a substantial component of the coastal tourism economies of, for example, Australia, Malaysia, South Africa and India. Even in the case of Thailand, the leading IORA destination for international travel, coastal domestic tourism is substantial and expanding rapidly with an increase in numbers of middle-income earners and of improved infrastructure (especially roads) to support local mobilities.

For one IORA state there is available a national data base that allows a reasonably accurate analysis to be offered of both the geography and the importance of coastal tourism relative to the country's tourism economy as a whole. In the case of South Africa the essential aspects of the characteristics and share of coastal tourism can be calculated using local level data which are provided in the IHS Global Insight data base. Tourism data was aggregated for the four South African coastal metropolitan municipalities (Cape 
Town, eThekwini, Nelson Mandela Bay, Buffalo City) and 11 coastal district municipalities (Rogerson \&Rogerson, 2020b). Several findings emerge from an analysis of 2015 data. First, South Africa's coastal destinations account for 28 \% total tourism trips, 33 \% bednights but $40 \%$ total tourism spend. Second, in terms of origin, coastal destinations are massively dominated by domestic as opposed to international tourists; in 2015 estimated domestic tourism trips were 9.8 million as compared to 1.6 million for international trips. In terms of geography it is revealed that coastal tourism is dominated by large urban centres; this finding supports the observation made by Prideaux (2009: 171) that coastal cities are now "larger and more significant centres for tourism activity than traditional seaside resorts". Indeed, it is revealed that the coastal tourism economy of South Africa is commanded by the metropolitan centres of Cape Town and eThekwini (Durban). Cape Town accounts for $41 \%$ total spend in coastal destinations and eThekwini a further $24 \%$ total spend; other notable coastal destinations as defined by total tourism spend are the district municipalities of Eden (8.0\%), Overberg (4.9\%) and Ugu (4.4\%). Total tourism spend is highly concentrated geographically with the five leading destinations responsible for $82 \%$ total tourism spend.

Analysis of the purpose of travel to coastal destinations reveals them to be multipurpose destinations (Rogerson \& Rogerson, 2017). The South African data discloses that of total trips to coastal destinations the major purpose of travel is for visiting friends and relatives (estimated 6.4 million), followed by leisure (2.9 million), business (1.3 million) and 'other' (0.3 million). Differences emerge between the different localities as to the particular significance of different forms of tourism. It is revealed that for all categories of tourism Cape Town and eThekwini are the major destinations; for VFR eThekwini is clearly most important (eThekwini 2.0 million, Cape Town o.9 million); for leisure and business the most important is marginally Cape Town (for leisure Cape Town 0.78 million trips vs eThekwini 0.75 million and for business Cape Town 0.4 million trips vs eThekwini 0.3 million). That said, as a result of high flows of VFR travel in terms of total tourism trips eThekwini is the most significant South African coastal destination accounting for $27.0 \%$ trips as opposed to $15.6 \%$ for Cape Town.

The differences between relative shares on total tourism trips as compared to total tourism spend reflect the lower spend per trip in eThekwini as compared to Cape Town and can be explained largely by the high number of low spend VFR trips to eThekwini. Finally, it is shown that in terms of recent change in tourism trends that the overall share of coastal tourism in total tourism in South Africa appears to be in relative decline mainly as a consequence of the post-2010 decline/stagnation in tourism and especially of the downturn in domestic tourism occasioned by poor economic conditions, state mismanagement and a resultant recessionary climate that has reduced household discretionary spending on travel (Rogerson \& Rogerson, 2020b).

\section{POLICY CHALLENGES FOR IORA STATES}

In terms of the future development of coastal tourism the works of Attri (2018) and Dwyer (2018) both caution of several broad challenges to the sustainable development of coastal and marine tourism across IORA states. First, is the threat of rapid and uncontrolled urbanisation with coastal development occurring in an unplanned, haphazard or undirected manner resulting in a downgrade of seascapes and landscapes (Papageorgiou, 2016). Along many of the coastlines of IORA states, notably Kenya, Mozambique and Tanzania (especially Zanzibar) Dwyer (2017: 43) points out "tourism has developed in a haphazard and unplanned fashion causing major social and environmental problems”. Such challenges, to a large extent, are an outcome of the inability of governments to enforce tourism land use management and development 
policies because of weak municipal governance, often a multiplicity of uncoordinated agencies, and sometimes exacerbated by illegal or corrupt practices (Lee, 2010). In Zanzibar Khamis et al. (2017) disclose the pressures on coastal environments from population increase, urbanization and expanding tourism and of the failure of ad hoc management practices. Local residents who depend on healthy ecosystems are at risk of losing their livelihoods with a degradation of marine and coastal environments. According to Dwyer (2017: 49) there can be observed a "failure of good governance of coastal and marine tourism in the IOR regionally, nationally and internationally".

Second, is the 'dependency' syndrome as coastal and marine destinations that overspecialize in tourism become vulnerable to crises within particular source markets or over-reliant on a particular tourism product (such as diving or beach recreation). Among others Farsari et al. (2007) highlight the threats of a tourism monoculture and of the imperative for tourism economies to become diversified. Biggs et al. (2015) maintain that the resilience of local tourism enterprises, in terms of their ability to adapt to or continue to function under changing pressures and circumstances, is critical for the future economic health of coastal and marine tourism. Third, is issues of access and infrastructural provision, the inadequacies of which limit the capacity for tourism to drive the potential for local economic development. This situation is especially problematic for peripheral or remote coastal destinations as is well-illustrated by the problems of tourism development along South Africa's Wild Coast (Kepe et al., 2001; Rogerson, 2019).

When building an infrastructure for tourism development, however, there is a danger if it is penetrating a previously coastal area dramatic transformative changes are set in motion which can result in conflicts between traditional ways of using coastal and marine spaces and of the needs of a modern tourism industry geared to the market expectations of international visitors (Käyhkö et al., 2019). As coastal spaces are not widely understood or respected as places of multiple values, needs and uses, often "new developments take place without the actors properly understanding either how the local communities have valued and used these spaces over the generations or how these traditions can be linked to improved means of development" (Käyhkö et al., 2019: 65).

Four, the impacts of other coastal activities, most notably industrial development, can threaten the integrity of coastal resources such as unpolluted beaches and waters (Gössling et al., 2018). This challenge has surfaced in several IORA states including India, Kenya and South Africa. For Zanzibar Gössling (2001) draws attention to critical infrastructural issues surrounding freshwater resources as a consequence of the demands from tourism. Five, human resource issues represent another critical issue for coastal and marine tourism enterprises because of seasonality and of limited long-term career pathways which result in difficulties in attracting or maintaining skilled personnel in order to sustain service quality and destination competitiveness (Dwyer, 2018).

$\mathrm{Six}$, for the competitiveness of tourism enterprises constant innovation is essential, including for coastal tourism businesses (Booyens, 2016). The ownership pattern in many coastal areas is often with a dominance by certain large enterprises (such as a hotel chain) and accompanied by the proliferation of small and medium-sized enterprises (SMEs), the latter with limited capacity for innovation and abilities to address core issues which constrain local destination development. The consequence of this situation of low levels of innovation is minimal creative potential for new product development and of reduced potential for local solutions addressing the development challenges of coastal destinations (Booyens \& Rogerson, 2017; Booyens \& Hart, 2019). Seven, as mentioned earlier, the absence of scientific data and regular monitoring of coastal and marine tourism undermines the possibility for informed and evidencebased policy development and reflects more generally poor governance processes 
(Dwyer, 2017). This underscores the need for improved data for monitoring tourism development trajectories and impacts in coastal communities as well as a strengthening of research capacity in order to provide evidenced-based analysis to support planning. An emerging body of work is demonstrating the potential of using participatory geospatial methodologies which "offer an opportunity to incorporate a community's place-based knowledge into the planning process” (Käyhkö, 2019: 65).

Eight, for local entrepreneurs access to finance is a pressing challenge, most especially for those who are seeking to establish or expand their businesses. In coastal areas of Kenya one of the major identified constraints for the development of SMES linked to tourism value chains is that of access to finance (Kenya Institute for Public Policy Research and Analysis, 2018). In remote areas of coastal Australia, Jacobsen (2017) shows how tourism SMEs operated by indigenous people struggle with issues of limited business skills. In addition to enterprise funding, finance and support is required also for research and development for innovation in order to support more broadly the long-term development of coastal and marine tourism (Hampton, 2013).

Nine, a critical contemporary challenge is that coastal and marine tourism is the segment of tourism most vulnerable and threatened by climate change and to the ramifications of extreme weather events (Moreno \& Amelung, 2009; Moreno \& Becken, 2009). In the case of Indonesia coastal tourism has been negatively impacted by climate change with many areas described as "really sensitive and vulnerable to the direct and indirect impacts of climate-related disasters" (Wijaya \& Furqan, 2018: 535). The threats of advancing climate change and its damage or destruction of tourism attractions are most acute in the context of Small Island Developing States (Hampton \& Jeyacheya, 2013, 2014). Rising sea levels and sea temperatures and increased severity of storms result in beach destruction and coral bleaching which degrade the coastal tourism product (Orams \& Luck, 2014; Gössling et al., 2018). The threats posed by climate change are of particular concern to those IORA states that are part of the global South where many countries do not perceive climate change as a policy priority (Mertz et al., 2009). As argued by Noome (2020: 28) the heightened vulnerability and a lower adaptive capacity due to differing socio-economic stressors results "in lower income countries, particularly in the Global South, have adaptation requirements that differ to developed countries in the Global North". Indeed, as is shown in the case of South Africa, in the short run other socio-economic stressors such as poverty or insufficient housing and infrastructure services are considered as higher and immediate policy priorities and of greater significance than pursuing action towards sustainable adaptation against climate change (Pandy \& Rogerson, 2020). Ten, an essential prerequisite for sustainable development is the imperative for economic inclusion and spreading the benefits of tourism growth to local communities with the outcomes for alleviating poverty, enhancing household livelihoods and improving practices for coastal management and conservation. Yet Dwyer (2018: 33) observes "progressive tourism business models that create local economic impacts and conservation incentives are much less developed in coastal areas". Further reducing the local impacts of certain kinds of coastal tourism is the high level of leakages which occur outside of coastal areas because of the narrow production base in many coastal and marine destinations. This situation constrains the development of 'pro-poor' local supply chains (Ashley et al., 2001; Torres \& Momsen, 2004; Kenya Institute for Public Policy Research and Analysis 2018).

Of significance for extending economic inclusion is the particular variant of coastal tourism in destinations. Globally, the economy of coastal and marine tourism "is dominated by mass tourism, involving the movement of large numbers of people on standardized packaged tour holidays" (Dwyer, 2017: 41). Within IORA states the best 
examples of such mass coastal tourism are evidenced by 'integrated' beach tourism resorts in coastal areas of Kenya, Thailand, Malaysia, Indonesia and Mauritius. Dwyer (2015) isolates several positive benefits from the growth of this form of coastal and marine tourism which typically involves large groups of international tourists in search of a 'sea, sun and sand destination". Among the benefits are those of stimulating local production, contributing to household incomes and standards of living, generating investment in new businesses, and catalysing the emergence of local businesses (Dwyer, 2015).

For other scholars all-inclusive beach resorts represent precisely the opposite of what is understood as 'inclusive tourism' (Shaw \& Shaw, 1999; Scheyvens \& Biddulph, 2018). In the context of Zanzibar Murphy (2019) documents clearly the practices and conjunctures of 'exclusionary development'. It is shown how local enterprises are increasingly marginal in Zanzibar tourism whilst large-scale resorts and non-local firms capture and subsequently offshore much of the value generated by the tourism industry (Murphy, 2019). Beyond the negative impacts of all-inclusive resorts, the all-inclusive cruise ship model of tourism, one which is increasingly expanding in IORA states, is under critical scrutiny for not creating sufficient local linkages for destinations. Cruise ships provide most services on board and, in some cases, even for land excursions occasionally they furnish passengers with food supplies from the ship thus again constraining opportunities for local entrepreneurs (Hampton \& Jeyacheya, 2013).

Arguably, in discussing the potential of economic inclusion in coastal and marine tourism there are a variety of different forms or models of coastal tourism that must be unpacked and assessed. Of particular importance is the need to differentiate the impacts and varying possibilities of coastal tourism focussed on international vs domestic or regional tourism, of mass vs alternative forms of tourism, and of high end or luxury forms of tourism vs budget tourism (Rogerson, 2020). Across the experience of 21 IORA states whilst most governments currently focus in tourism development planning on going 'up-scale' and seek to attract the markets of high end international tourists or mass international travel, a caution must be sounded as to whether this is the most appropriate choice. Among others Scheyvens (2002a, 2007, 2011) and Hampton (1998, 2003, 2013) draw attention to the promise for an inclusive tourism pathway from targeting alternative forms of tourist such as domestic travellers or providing for the market needs of backpackers which is a tourist niche that most governments continue to ignore in terms of tourism policy (Martins \& Costa, 2017).

Scheyvens (2002b: 145) argues that as a whole "there is much to gain from going low" and that governments should re-consider the hegemonic models of tourism policy. Similar sentiments are expressed about the prospects for inclusive coastal tourism development in South Africa where national government policy commitments include promoting inclusive tourism (Rogerson, 2020).

\section{CONCLUSION}

Coastal and marine tourism is a vital and expanding segment of the global tourism economy and the recreational use of the sea and coastal sites is expected to grow in future (Carvache-Franco et al., 2020). Across IORA states coastal and marine tourism is acknowledged as a critical sector of the blue economy (Attri \& Bohler-Muller, 2018).

Against this backdrop the objective in this article was to scrutinize the role of coastal and marine tourism across IORA and to identify a set of generic policy challenges with a specific focus on economic inclusion. In reviewing the discussion the extraordinary diversity of countries represented in IORA must be acknowledged from Australia or Thailand on the one hand to Yemen or Somalia on the other. UNWTO baseline data on international tourism discloses the uneven spatial development of 
tourism across the 21 IORA states. However, UNWTO data masks the role of intraregional travel or regional tourism which is a major constituent in the tourism economies of several IORA states. Further, the critical role of domestic tourism is hidden in UNWTO data albeit it is larger numerically than international tourism, and demonstrated to be a substantial element in the economy of many coastal destinations.

Arguably, significant assets of coastal and marine tourism offer considerable potential for tourism development across IORA states. Tourism growth is an external factor that is dramatically reshaping many coastal spaces and environments (Käyhkö et al., 2019). It has been highlighted that multiple challenges face the sustainable development of coastal and marine tourism as a whole, including lack of (or inappropriate) planning for coastal area development and the (mis-)management, governance issues, limited innovation, constrained access to finance for enterprise development, absence of data for monitoring, and, the severe threats posed to coastal destinations from advancing climate change. Above all, one critical issue is the imperative for economic inclusion and of achieving a greater spread of the benefits of tourism growth to local communities and especially for marginalised groups. Addressing this challenge of inclusion demands at the outset an improvement in data concerning coastal communities alongside a strengthened research base that incorporates local knowledge to inform planning for economic inclusion through evidence-based findings. In addition, it is contended that for many IORA states it might require also a fundamental rethink of the dominant planning model around encouraging mass international tourism which is often concentrated on all-inclusive resorts. Instead, what is needed is reconsideration of the potential for leveraging benefits from promoting domestic and regional tourism as well as of budget forms of international tourism.

\section{Acknowledgements}

Thanks are due to the South African Institute of International Affairs for funding this research and to the expert comments which were received for revision of earlier drafts of this material. Skye Norfolk gave useful inputs.

\section{REFERENCES}

Agarwal, S. \& Shaw, G. (2007). Managing Coastal Tourism Resorts: A Global Phenomenon. Clevedon: Channel View, eds.

Al Busaidi, M., Bose, S. \& Claereboudt, M. (2019). Sea Turtles Tourism in Oman: Current Status and Future Prospects. Tourism and Hospitality Research, 19 (3), 321-336.

Anderson, W. (2013). Leakages in the Coastal Systems: Case of Zanzibar. Tourism Review, 68 (1), $62-75$.

Ashley, C., Roe, D. \& Goodwin, H. (2001). Pro-Poor Tourism: Putting Poverty at the Heart of the Tourism Agenda. London: Overseas Development Institute.

Attri, V.N. (2017). Socio-economic Development in IORA: Relevance of Shared Socio-economic Pathways (SSPS) For Climate Change Impact. Journal of Indian Ocean Rim Studies, 1 (1), 107-137.

Attri, V.N. (2018). The Role of Marine Tourism in IORA: The Pathways Ahead. Paper presented at the 3 rd Tourism Experts Meeting for the Establishment of the IORA Core Group on Tourism, Durban, 6-8 May.

Attri, V.N. (2019). Indo-Pacific Construct: Evolving an IORA's Perspective in Terms of Strategic Regional Economic Cooperation. Journal of Indian Ocean Rim Studies, 2 (2 Special Issue), 11-57.

Attri, V.N. \& Bohler-Muller, N. (2018). The Blue Economy Handbook of the Indian Ocean Region. Pretoria: Africa Institute,eds.

Biddulph, R. \& Scheyvens, R. (2018). Introducing Inclusive Tourism. Tourism Geographies, 20 (4), $583-588$.

Biggs, Hicks, C.C., Cinner, J.E., \& Hall, C.M. (2015). Marine Tourism in the Face of Global Change: The Resilience of Enterprises to Crises in Thailand and Australia. Ocean and Coastal Management, 105, 65-74.

Bob, U., Swart, K., Ngalawa, H. \& Nzimande, N. (2018). Methodological Challenges in Assessing the Economic Impacts of Coastal and Marine Tourism in South Africa: Reflections from a Piloting Project. Euroeconomica, 37 (1), 202-217.

Booyens, I. (2016). Global-local Trajectories for Regional Competitiveness: Tourism Innovation in the Western Cape. Local Economy, 31 (1-2), 142-157. 
Booyens, I. \& Hart, T. (2019). Innovation in a Changing South Africa: Extant Debates and Critical Reflections. In J. Knight \& C.M. Rogerson (eds.), The Geography of South Africa: Contemporary Changes and New Directions. Cham, Switzerland: Springer International, 269-277.

Booyens, I. \& Rogerson, C.M. (2017). Networking and Learning for Tourism Innovation: Evidence from the Western Cape. Tourism Geographies, 19 (3), 340-361.

Carvache-Franco, W., Carvache-Franco, M., Carvache-Franco, O. \& Hernández-Lara, A.B. (2020). Motivation and Segmentation of the Demand for Coastal and Marine Destinations. Tourism Management, 24, 100661.

Cohen, E. \& Cohen, S.A. (2015). A Mobilities Approach to Tourism from Emerging World Regions. Current Issues in Tourism, 18 (1), 11-43.

Colgan, C.S. (2017). The Blue Economy of the Indian Ocean: Context and Challenge. Journal of Indian Ocean Rim Studies, 1 (1), 7-37.

Daldeniz, B. \& Hampton, M. P. (2013). Dive Tourism and Local Communities: Active Participation or Subject to Impacts?: Case Studies from Malaysia. International Journal of Tourism Research, 15, 507-520.

De Brauwer, M., Harvey, E.S., McIlwain, J.L., Hobbs, J-P. A, Jompa, J. \& Burton, M. (2017). The Economic Contribution of the Muck Dive Industry to Tourism in Southeast Asia. Marine Policy, 83, 92-99.

Doyle, T. (2018). Blue Economy and the Indian Ocean Rim. Journal of the Indian Ocean Region, 14 (1), 1-6.

Dwyer, L. (2015). Globalisation of Tourism: Drivers and Outcomes. Tourism Recreation Research, 40 (3), 326-339.

Dwyer, L. (2017). Coastal and Marine Tourism in the Indian Ocean Rim: Challenges and Opportunities. Journal of Indian Ocean Rim Studies, 1 (1), 38-55.

Dwyer, L. (2018). Emerging Ocean Industries: Implications for Sustainable Tourism Development. Tourism in Marine Environments, 13 (1), 25-40.

Farsari, Y., Butler, R. \& Prastacos, P. (2007). Sustainable Tourism Policy for Mediterranean Destinations: Issues and Interrelationships. International Journal of Tourism Policy, 1 (1), 58-78.

Ghimire, K. ed. (2001). The Native Tourist: Mass Tourism Within Developing Countries. London: Earthscan.

Gössling, S. (2001). The Consequences of Tourism For Sustainable Water Use on a Tropical Island: Zanzibar, Tanzania. Journal of Environmental Management, 61 (2), 179-191.

Gössling, S., Hall, C.M. \& Scott, D. (2018). Coastal and Ocean Tourism. In M. Salomon \& T. Markus (eds.), Handbook on Marine Environment Protection, Cham, Switzerland: Springer International, 773-790.

Gupta, P. (2015). Consuming the Coast: Mid-century Communications of Port Tourism in the Southern African Indian Ocean. Comunicação Midia e Consumo, 12 (35), 149-170.

Hall, C.M. (2001). Trends in Ocean and Coastal Tourism: The End of the Last Frontier? Ocean and Coastal Management, 44 (9-10), 601-618.

Hampton, M. (1998). Backpacker Tourism and Economic Development. Annals of Tourism Research, 25, 639-66o.

Hampton, M. (2003). Entry Points for Local Tourism in Developing Countries: Evidence from Yogyakarta, Indonesia. Geografiska Annaler 85B (2), 85-101.

Hampton, M. (2013). Backpacker Tourism and Economic Development: Perspectives from the Less Developed World. London: Routledge.

Hampton, M. \& Jeyacheya, J. (2013). Tourism and Inclusive Growth in Small Island Developing Countries. London: The Commonwealth Secretariat.

Hampton, M. \& Jeyacheya, J. (2014). Coastal Tourism and Local Impact at Ngapali Beach: Initial Findings. Unpublished report, University of Kent, Canterbury.

Hampton, M., Jeyacheya, J. \& Long, P.H. (2018). Can Tourism Promote Inclusive Growth?: Supply Chains, Ownership and Employment in Ha Long Bay, Vietnam. The Journal of Development Studies, 54 (2), 359-376.

Harriott, V. (2004). Marine Tourism Impacts on the Great Barrier Reef. Tourism in Marine Environments, 1 (1), $29-40$.

Honey, M. \& Krantz, D. (2007). Global Trends in Coastal Tourism. Washington DC: World Wildlife Fund Marine Program.

Hussain, M.G., Failler, P., Al Karim, A. \& Alam, M.K. (2018). Major Opportunities of Blue Economy Development in Bangladesh. Journal of the Indian Ocean Region, 14 (1), 88-99.

Jacobsen, D. (2017). Tourism Enterprises Beyond the Margins: The Relational Practices of Aboriginal and Torres Strait Islander SMEs in remote Australia. Tourism Planning \& Development, 14 (1), 31-49.

Käyhkö, N., Khamis, Z.A., Eilola, S., Virtanen, E., Muhammad, M.J., Viitasalo, M. \& Fagerholm, N. (2019). The Role of Place-Based Local Knowledge in Supporting Integrated Coastal and Marine Spatial Planning in Zanzibar, Tanzania. Ocean and Coastal Management, 177, 64-75.

Kenya Institute for Public Policy Research and Analysis (2018). Economic Inclusion Through Small-Medium Enterprise Development in Coastal Tourism. Report prepared for the South African Institute of International Affairs, Cape Town.

Kepe, T., Ntsebeza, L. \& Pithers, L. (2001). Agri-Tourism Spatial Development Initiatives in South Africa: Are They Enhancing Rural Livelihoods?. London: Overseas Development Institute, Natural Resource Perspectives No. 65 .

Khamis, Z.A., Kalliola, R. \& Käyhkö, N. (2017). Geographical Characterization of the Zanzibar Coastal Zone and Its Management Perspectives. Ocean and Coastal Management, 149, 116-134. 
Kinseng, R.A., Nasdian, F.T., Fatchiya, A., Mahmud, A. \& Stanford, R.J. (2018). Marine-tourism Development on a Small Island in Indonesia: Blessing or Curse?. Asia Pacific Journal of Tourism Research, 23 (11), 1062-1072.

Kotze, J.S. \& Bohler-Muller, N. (2018). 'Let's Talk about Sex': The State of Gender in IORA for a Future Agenda. Journal of the Indian Ocean Region, 14 (2), 130-151.

Lee, O.A. (2010). Coastal Resort Development in Malaysia: A Review of Policy Use in the Pre-construction and Post-construction Phase. Ocean and Coastal Management, 53 (8), 439-446.

Leijzer, M. \& Denman, R. (2014). Tourism Development in Coastal Areas in Africa: Promoting Sustainability Through Governance and Management Mechanism. Unpublished paper UNWTO, Madrid, Spain.

Llewellyn, L.E., English, S. \& Barnwell, S. (2016). A Roadmap to a Sustainable Indian Ocean Blue Economy. Journal of the Indian Ocean Region, 12 (1), 52-66.

Manwa, H. (2019). Cultural and Heritage Tourism Competitiveness Within the Indian Ocean Rim Countries. Journal of Indian Ocean Rim Studies, 2 (1), 111-131.

Martins, M. R. \& Costa, R.A. (2017). Backpackers' Contribution to Development and Poverty Alleviation: Myth or Reality? A Critical Review of the Literature and Directions For Future Research. European Journal of Tourism Research, 16, 136-153.

Mertz, O., Halsnaes, K., Olesen, J.E. \& Rasmussen, K. (2009). Adaptation to Climate Change in Developing Countries. Environmental Management, 43 (5), 743-752.

Miller, M.L. (1993). The Rise of Coastal and Marine Tourism. Ocean and Coastal Management, 20, $181-199$.

Miller, M.L. \& Anyong, J. (1991). Coastal Zone Tourism: A Potent Force Affecting Environment and Society. Marine Policy, 15 (2), 75-98.

Mittra, S. (2017). Blue Economy: Beyond An Economic Proposition. New Delhi, Observer Research Foundation Issue No. 173.

Moreno, A. \& Amelung, B. (2009). Climate Change and Coastal \& Marine Tourism: Review and Analysis. Journal of Coastal Research, SI 56, 1140-1144.

Moreno, A. \& Becken, S. (2009). A Climate Change Vulnerability Assessment Methodology for Coastal Tourism. Journal of Sustainable Tourism, 17 (4), 473-488.

Murphy, J. (2019). Global Production Network Dis/Articulations in Zanzibar: Practices and Conjunctures of Exclusionary Development in the Tourism Industry. Journal of Economic Geography, 19 (4), 943-971.

Noome, K. (2020). An Assessment of the Climatic Suitability of Namibia for Tourism using the Tourism Climate Index (TCI). MSc dissertation (Geography and Environmental Studies), University of Witwatersrand, Johannesburg.

Orams, M.B. \& Luck, M. (2014). Coastal and Marine Tourism. In C.M. Hall, A. Lew \& M. Williams (eds), The Wiley-Blackwell Companion to Tourism. London: Blackwell, 479-489.

Pandy, W. \& Rogerson, C.M. (2020). Tourism Industry Perspectives on Climate Change in South Africa. In J. M. Rogerson \& G. Visser (eds.), New Directions in South African Tourism Geographies. Cham, Switzerland: Springer International, 93-111.

Papageorgiou, M. (2016). Coastal and Marine Tourism: A Challenging Factor in Marine Spatial Planning. Ocean and Coastal Management, 129, 44-48.

Potgieter, T. (2018). Oceans Economy, Blue Economy, and Security: Notes on the South African Potential and Developments. Journal of the Indian Ocean Region, 14 (1), 49-70.

Prideaux, B. (2004). The Resort Development Spectrum: The Case of the Gold Coast, Australia. Tourism Geographies, 6 (1), 26-58.

Prideaux, B. (2009). Resort Destinations: Evolution, Management and Development. Oxford: ButterworthHeinemann.

Rahman, M.D.S. (2015). Coastal Tourism Development: Case Study Cox's Bazar, Bangladesh. Masters thesis, Centria University of Applied Sciences, Kokkola, Finland.

Rimmer, S.H. (2017). The Future of Women's Economic Empowerment in the Indian Ocean Region: Governance Challenges and Opportunities. Journal of the Indian Ocean Region, 13 (1), 4-24.

Rogerson, C.M. (2004). Regional Tourism in South Africa: A Case of 'Mass Tourism of the South'. GeoJournal of Tourism and Geosites, 60, 229-237.

Rogerson, C.M. (2019). Peripheral Tourism Trajectories: Evidence from King Sabata Dalindyebo Municipality, South Africa. GeoJournal of Tourism and Geosites, 26 (3), 974-992.

Rogerson, C.M. (2020). In Search of Inclusive Tourism in South Africa: Some Lessons from the International Experience. In J. M. Rogerson \& G. Visser (eds.), New Directions in South African Tourism Geographies. Cham, Switzerland: Springer International, 147-166.

Rogerson, C.M. \& Rogerson, J.M. (2017). City Tourism in South Africa: Diversity and Change. Tourism Review International, 21 (2), 193-211.

Rogerson, C.M. \& Rogerson, J.M. (2019a). Emergent Planning for South Africa's Blue Economy: Evidence from Coastal and Marine Tourism. Urbani izziv 30 (Supplement), 24-36.

Rogerson, C.M. \& Rogerson, J.M. (2019b). Tourism, Local Economic Development and Inclusion: Evidence from Overstrand Local Municipality, South Africa. GeoJournal of Tourism and Geosites, 25 (2), 293-308. 
Rogerson, C.M. \& Rogerson, J.M. (2020a). Resort Development and Pathways in South Africa: Hermanus, 1890-1994. In J. M. Rogerson \& G. Visser (eds.), New Directions in South African Tourism Geographies. Cham, Switzerland: Springer International, 15-32.

Rogerson, C.M. \& Rogerson, J.M. (2020b). Coastal Tourism in South Africa: A Geographical Perspective. In J. M. Rogerson \& G. Visser (eds.), New Directions in South African Tourism Geographies. Cham, Switzerland: Springer International, 227-247.

Scheyvens, R. (1999). Ecotourism and the Empowerment of Local Communities. Tourism Management, 20 (2), 245-249.

Scheyvens, R. (2002a). Tourism for Development: Empowering Communities. Harlow: Prentice Hall.

Scheyvens, R. (2002b). Backpacker Tourism and Third World Development. Annals of Tourism Research, 29 (1), 144-164.

Scheyvens, R. (2007). Poor Cousins No More: Valuing the Development Potential of Domestic and Diaspora Tourism. Progress in Development Studies, 7 (4), 307-325.

Scheyvens, R. (2011). Tourism and Poverty. London: Routledge.

Scheyvens, R. \& Biddulph, R. (2018). Inclusive Tourism Development. Tourism Geographies, 20 (4), 589-6o9.

Shaw, B.J. \& Shaw, G. (1999). 'Sun, Sand and Sales': Enclave Tourism and Local Entrepreneurship in Indonesia. Current Issues in Tourism, 2 (1), 68-81.

Snyman, S. \& Spenceley, A. (2019). Private Sector Tourism in Conservation Areas in Africa. Wallingford, UK: CABI publishers.

Spalding, M., Burke, L., Wood, S.A., Ashpole, J., Hutchinson, J. \& zu Ermgassen, P. (2017). Mapping the Global Value and Distribution of Coral Reef Tourism. Marine Policy, 82, 104-113.

Tibirica, Y., Birtles, A., Valentine, P. \& Miller, D.K. (2011). Diving Tourism in Mozambique: An Opportunity at Risk? Tourism in Marine Environments, 7 (3-4), 141-151.

Torres, R. \& Momsen, J. (2004). Challenges and Potential for Linking Tourism and Agriculture To Achieve Propoor Tourism Objectives. Progress in Development Studies 4 (4), 294-318.

Van Putten, I., Cvitanovic, C. \& Fulton, E.A. (2016). A Changing Marine Sector in Australian Coastal Communities: An Analysis of Inter and Intra Sectoral Industry Connections and Employment. Ocean and Coastal Management, 131, 1-12.

Venables, S., Winstanley, G., Bowles, L. \& Marshall, A.D. (2016). A Giant Opportunity: The Economic Impact of Manta Rays on the Mozambican Tourism Industry - An Incentive for Increased Management and Protection. Tourism in Marine Environments, 12 (1), 51-68.

Verma, N. \& Jolly, V. (2019). Conceptualisation and Emerging Classification of Blue Economy. Journal of Indian Ocean Rim Studies, 2 (1), 46-70.

Walton, J. (2016). Seaside Resorts and International Tourism. In E.G.E. Zuelow (ed.), Tourism Beyond the Nation: A Transnational Approach to European Tourism History. London: Routledge, 33-50.

Wijaya, N. \& Furqan, A. (2018). Coastal Tourism and Climate-Related Disasters in an Archipelago Country of Indonesia: Tourists' Perspectives. Procedia Engineering, 212, 535-542.

Wilson, D. (1997). Paradoxes of Tourism in Goa. Annals of Tourism Research, 24 (1), 52-75.

Wong, P.P. (1986). Tourism Development and Resorts on the East Coast of Peninsular Malaysia. Singapore Journal of Tropical Geography, 7 (2), 152-162.

Wonga, P.P. (1998). Coastal Tourism Development in Southeast Asia: Relevance and Lessons for Coastal Zone Management. Ocean and Coastal Management, 38 (2), 89-109.

*** Indian Ocean Rim Association (2018). Promoting Coastal and Marine Tourism: Tourism and Cultural Exchanges. Available at http://www.iora.net/en/events-media-news-updates-folder [Accessed 20 May 2018].

*** Indian Ocean Research Group (2010). Editorial Essay: Research Agendas for the Indian Ocean Region. Journal of the Indian Ocean Region, 6 (1), 1-25.

*** Indian Ocean Rim Association (2017). Declaration of the Indian Ocean Rim Association on the Blue Economy in the Indian Ocean Region. Jakarta: IORA.

*** The COAST Project (2013). Kenya. The COAST Project Newsletter, 5 th Quarterly Newsletter.

*** UNCTAD (2017). Economic Development in Africa Report 2017: Tourism for Transformative and Inclusive Growth. Geneva; UNCTAD.

*** UNWTO (2013). Message from the Executive Director - UNWTO. The COAST Project Newsletter, 5th Quarterly Newsletter, 3 .

*** UNWTO (2017). UNWTO Tourism Highlights. Madrid: UNWTO.

*** World Bank (2017). Tourism for Development: 20 Reasons Sustainable Tourism Counts for Development. Washington DC: The World Bank.

Submitted:

30.01.2020
Revised:

30.04.2020
Accepted and published online 11.05.2020 